\title{
Fenomena Sosial Pilihan Hidup Tidak Menikah Wanita Karier
}

\author{
Indri Wulandari
}

\author{
Nursalam \\ Universitas Muhammadiyah Makassar \\ nursalam@unismuh.ac.id
}

\author{
Mas'ud Ibrahim \\ Universitas Muhammadiyah Makassar \\ masudibrahim@unismuh.ac.id
}

\begin{abstract}
ABSTRAK
Masalah utama dalam penelitian ini adalah latar belakang pilihan hidup tidak menikah dan bagaimana interaksi wanita karier yang tidak menikah di dalam masyarakat.. Penelitian ini adalah jenis penelitian kualitatif deskriftif, meliputi rangkaian kegiatan yang sistematik untuk mendapatkan jawaban atas permasalahan yang diajukan. Jika dilihat dari jenis obyek yang diteliti, maka penelitian ini di kategorikan sebagai penelitian studi kasus dengan maksud memberikan gambaran tentang Fenomena sosial pilihan hidup tidak menikah (pada wanita karier di Kota Ende Kabupaten Ende). Hasil penelitian menunjukkan bahwa: (1) faktor yang melatar belakangi wanita karier memilih hidup melajang yaitu; terlanjur memikirkan karier dan pekerjaannya, adanya prioritas-prioritas kehidupan lainnya, ingin menjalani kehidupan pribadi secara bebas, perasaan dibutuhkan oleh keluarganya di rumah, serta ketakutan akan permasalahan dan konflik rumah tangga. (2) Interaksi antara masyarakat sekitar dengan wanita karier bisa dikatakan harmonis. Bergotong royong dalam pelaksanaan kegiatan-kegiatan kemasyarakatan tetap terlaksana.Wanita karier dengan segala aktifitasnya, tidak mengurangi partisipasi dalam kelancaran semua aktifitas sosial.Masyarakat sekitar menerima secara positif keputusan yang diambil wanta-wanita karier tersebut. Melihat sikap yang ditunjukan tidak pernah menunjukan kesan negative sebab wanita karier yang memiih hidup melajang selalu menjaga norma masyarakat.
\end{abstract}

Kata Kunci : Wanita Karier, Tidak Menikah, Pilihan Hidup.

\section{PENDAHULUAN}

Kesetaraan antara wanita dan laki-laki boleh disebut mengalami kemajuan pesat.Sejumlah lowongan pekerjaan yang dulu menjadi "kapling laki-laki", saat ini sudah banyak diisi dan dijalani wanita dengan prestasi mengesankan.Masyarakat awam pun kagum melihat ketegaran kaum wanita menembus dan mengalahkan "kungkungan budaya" yang menyebabkan mereka tidak boleh berperan dalam pekerjaan yang dinilai berbahaya.Kungkungan budaya yang dulunya kuat sehingga anak wanitadipingit dan dibatasi ruang geraknya, kini tidak lagi efektif.Saat ini ruang gerak wanita tidak lagi hanya sebatas "dapur, sumur dan kasur.menurut Riyanto (2005: 34)

Saat ini sasaran wanita bekerja lebih dari sekedar memperoleh penghasilan, namun juga ingin berprestasi, bermakna bagi orang lain, mengaktualisasikan diri dan mengubah image yang selama ini menyatakan mereka tidak memiliki kemampuan 
bekerja optimal. Kesetaraan gender telah menjadi isu internasional, hal ini ditunjukan dengan gerakan feminism yang cenderung radikal di dunia barat. Di dunia barat, karier sudah menjadi jamak dan menjadi pilihan hidup yang utama bagi wanita.Sementara berkeluarga dan melahirkan anak-anak seringkali menjadi pilihan hidup nomor dua.Karier menjadi lebih menarik dan lebih "dihargai" dibandingkan berkutat dengan urusan anak dan rumah tangga. Kartini (2005: 35). Wanita bekerja atau sering kita sebut dengan Wanita Karier kini menjadi topik hangat untuk diperbincangkan.Sebab banyak fenomena-fenomena yang terjadi seperti pilihan hidup tidak menikah pada wanita karier.

Terjadi perubahan penting dalam masalah perkawinan selama dua puluh tahun terakhir. Menurut Eriany (1997: 1) yaitu perkawinan tidak lagi dianggap sebagai gaya hidup yang cocok bagi semua orang, seringkali ditunda, semakin banyak pasangan yang hidup bersama tanpa ikatan perkawinan yang sah dan semakin banyak wanita bekerja dan mempunyai anak bekerja diluar rumah dan ikut mencari nafkah. Dengan melihat fenomena-fenomena diatas maka terlihat bahwa saat ini terdapat beberapa orang yang digolongkan sudah cukup usia namun belum menikah, yang biasanya kita sebut dengan sebutan melajang. Berdasarkan jajak pendapat yang dilakukan surat kabar Yomuiri di jepang, 7 dari 10 wanita lajang di jepang yakin mereka benar-benar bahagia dengan hidup sendiri atau tidak menikah. Jumlah wanita yang kurang berminat menikah ini terus meningkat rata-rata 10 persen dari tahun ke tahun.Apalagi hidup melajang tidak lagi dipandang buruk seperti di jaman dulu. Di Jerman, hasil survey yang dilakukan majalah stern ditemukan bahwa lebih dari 80 persen wanita single jerman benar-benar merasa bahagia tanpa keberadaan suami. Mereka juga mengatakan, hidup sendiri memberikan kebebasan untuk melakukan semua hal yang diinginkan. Dari 1.003 orang wanita yang ditanyai, hanya 2 persen yang menyatakan tidak bahagia berstatus single.sebanyak 36 persen mengatakan akan tetap single karena lebih menyenangkan. Hamper 50 persen wanita itu mengatakan lebih suka single karena membuat rumah mereka akan tetap rapi. Jumlah ini semakin besar prosentasenya seiring dengan perkembangan jaman, dimana menurut data jumlah wanita lajang semakin meningkat sebesar 58 persen pada tahun 2005, dan jumlah ini akan terus mengalami kenaikan sebesar 0,75 persen di tahun-tahun mendatang dalam kompas, 3 Maret 2005: 2 (Caecilia, 2006: 20). Dengan melihat fenomena sosial diatas, maka peneliti tertarik melakukan penelitian dengan judul "Fenomena Sosial Pilihan Hidup Tidak Menikah (Pada Wanita Karier Di Kota Ende Kabupaten Ende)" 


\section{LANDASAN TEORI}

Fenomena adalah rangkaian peristiwa serta bentuk keadaan yang dapat diamati dan dinilai lewat kaca mata ilmiah atau lewat disiplin ilmu tertentu. Fenomena juga bisa disebut hal yang luar biasa dalam kehidupan di dunia dan dapat terjadi dengan tidak terduga dan tampak mustahil dalam pandangan manusia, Suatu peristiwa yang tidak biasa tapi sering terjadi, pada alam atau mahkluk.Fenomena yang biasa kita ketahui adalah fenomena alam dan fenomena sosial, Fenomena sosial dapat diartikan sebagai gejala-gejala atau peristiwa-peristiwa yang terjadi dan dapat diamati dalam kehidupan sosialnya. Salah satu fenomena sosial yang terdapat dalam kehidupan kita sehari-hari adalah adanya masalah-masalah sosial yang timbul baik dalam kehidupan keluarga maupun masyarakat. Pengertian fenomena sosial adalah kondisi di mana manusia menganggap segala hal yang dialaminya adalah sebuah kebenaran absolut.Padahal, hal itu sebenarnya adalah kebenaran semu yang dibuat melalui simulasi simbol-simbol, kode-kode yang dicitrakan sedemikian dari sebuah objek yang benar.

Pengertian wanita karier dalam Kamus Besar Bahasa Indonesia, "Wanita” berarti perempuan dewasa.Sedangkan "Karier" berarti seseorang yang berkecimpung dalam kegiatan profesi (usaha, perkantoran, dsb).Karier adalah pekerjaan yang memberikan harapan untuk maju.Oleh karena itu, karier selalu dikaitkan dengan uang dan kuasa. Namun bagi sebagian yang lain, masalah tentu bukan sekedar itu, karier juga merupakan karya yang tidak dapat dipisahkan dengan panggilan hidup.Menurut Dariyo (2003: 69) karier mengandung pengertian suatu pilihan pekerjaan yang dilakukan individu, sesuai dengan kepribadian, minat-bakat, kemampuan, keterampilan ataupun kecerdasan. Menurut Gibson dkk, (1990: 206) karier adalah urutan sikap dan perilaku seseorang dikaitkan dengan pengalaman kerja dan aktivitas dalam rentang kehidupan orang itu. Dikatakan pula oleh Gibson bahwa karier tercermin dalam gagasan bergerak ke atas pada pilihan lain kerja seseorang. Istilah bergerak ke atas diartikan sebagai hak mendapatkan pendapatan, status, prestasi dan kuasa yang lebih besar.

Secara etimologis kata feminism berasal dari bahasa latin, yaitu femina yang dalam bahasa inggris diterjemahkan menjadi feminine artinya memiliki sifat-sifat seperti perempuan.Dalam pengertian yang lebih luas, feminism sekurang-kurangnya mencakup tiga pengertian pokok. Pertama, feminism merupakan pengalaman hidup, sebab ia tidak terlepas dari sejarah munculnya, yaitu dari masyarakat patriarkhi. Dari sejarah hidup inilah kemudian lahirlah kaum perempuan yang mempunyai kesadaran feminis.Kedua, feminis sebagai alat perjuangan politik bagi kebebasan manusia.Berangkat dari kesadaran 
feminism inilah, perempuan ingin melepaskan diri dari penindasan dan ketidakadilan yang selama ini dialaminya. Perjuangannya itu diletakkan dalam bentuk persamaan hokum (legal status) hak memilih dan kesetaraan dengan laki-laki..Feminisme (tokohnya disebut Feminis) adalah sebuah gerakan wanita yang menuntutemansipasi atau kesamaan dan keadilan hak dengan pria.Feminisme berasal dari bahasa Latin, femina atau wanita.Istilah ini mulai digunakan pada tahun 1890-an, mengacu pada teori kesetaraan laki-laki dan perempuan serta pergerakan untuk memperoleh hak-hak perempuan.Sekarang ini kepustakaan internasional mendefinisikannya sebagai pembedaan terhadap hak hak perempuan yang didasarkan pada kesetaraan perempuan dan laki laki.Feminisme menurut Goefe dalam Sugihastuti dan Suharto (2002: 18) adalah teori tentang permasalahan hak antara laki-laki dan wanita disegala bidang.Suatu kegiatan terorganisasi yang memperjuangkan hak-hak serta kepentingan perempuan. Hal ini disebabkan karena wanita selalu mengalami ketimpangan gender selama ini.

Istilah lajang menurut Kamus besar bahasa Indonesia, (2005: 262) merupakan sebutan bagi mereka yang belum menikah dalam arti belum pernah mempunyai suami atau isteri. Orang lajang didefinisikan sebagai pria atau wanita diatas 25 tahun yang belum menikah bekerja atau tidak mempunyai pekerjaan untuk memelihara anak, wanita karier lajang adalah wanita bekerja belum pernah menikah dan berusia lebih dari tiga puluh tahunan yang memutuskan untuk hidup melajang.

Tujuan dari sebagian besar wanita yang belum menikah selama usia dua puluh tahunan adalah perkawinan. Namun apabila dia belum menikah pada waktu dia telah mencapai usia tiga puluh atau persis pada ulang tahun yang ke tiga puluh, mereka cenderung untuk menukar tujuan dan nilai hidupnya ke arah nilai dan tujuan serta gaya hidup baru yang berorientasi pada pekerjaan, kesuksesan dalam karier dan kesenangan pribadi. Usia tiga puluh disebut usia kritis (critical age) bagi wanita yang belum menikah. Kehidupan wanita sering diwarnai stress ketika dia mencapai ulang tahunnya yang ke tiga puluh, namun ia belum juga menikah. Stress ini biasanya mencapai puncaknya pada usia tiga puluh, kemudian secara bertahap berkurang karena dia mulai menyesuaikan diri dengan gaya hidup yang lain dan baru. Bagi kebanyakan wanita, keinginan untuk menikah dan berkeluarga berkurang setelah usia tiga puluh karena mereka sadar bahwa nampaknya mereka tidak mencapai tujuannya. Gaya hidup yang dijalani oleh para wanita yang melewati usia tiga puluh ini, dikenal dengan istilah melajang menurut Hurlock (2004: 300).Gilang, 2000: 1 (Caecilia, 2007: 28) berpendapat bahwa saat ini terlihat adanya perubahan nilai dalam masyarakat, menurutnya bahwa peran gender tradisional 
telah berubah menjadi gender modern. Pada gender tradisional keinginan untuk menikah demikian besar. Pada gender modern, terlihat untuk lebih cenderung menunda pernikahan. Para wanita akan lebih menitikberatkan dirinya pada karier atau pekerjaan. Hal ini dipicu pula dengan tumbuhnya faham feminisme di kalangan wanita kota, yang menyebutkan bahwa wanita tidak harus bergantung pada laki-laki. Menurut Dariyo (2003: 143) sebagian orang yang menempuh cara hidup melajang karena didasari beberapa faktor, yaitu (1) masalah ideology atau panggilan dalam agama. Individu yang mempercayai suatu keyakinan tertentu, misalnya ideology politik atau agama tertentu akan berusaha mempertahankan keyakinan tersebut. Oleh karena itu ia memilih untuk tidak menikah. (2) Trauma perceraian Peristiwa perceraian memberikan dampak luka bathin yang tidak dapat dilupakan seumur hidup bagi individu yang mengala. inya, baik wanita maupun laki-laki. Perasaan terluka ini seringkali menyebabkan perubahan sikap dan kepribadian seseorang. Individu yang pernah mengalami perceraian dan merasakan sakit hati, kemungkinan akan mengambil keputusan untuk hidup melajang. (3) Tidak memperoleh jodoh. Sebagian orang yang melajang beralasan bahwa mereka merasa belum cocok karena tidak sesuai dengan criteria pilihannya atau merasa trauma dengan pengalaman masa lalu karena ditinggalkan atau dipermainkan pacarnya.Individu yang mengalami pengalaman tidak menyenangkan dimasa lalunya memiliki kecenderungan untuk tidak berumah tangga. (4) Terlanjur memikirkan karier dan pekerjaannya. Individu yang mencapai jenjang karier yang tinggi akan merasa kesulitan memperoleh jodoh yang diharapkan karena mereka menetapkan standar yang tinggi bagi calon pasangannya, sehingga setiap calon pasangan yang datang tidak sesuai dengan criteria yang ditetapkan. (5) Ingin menjalani kehidupan pribadi secara bebas. Hidup sendiri adalah hidup yang bertujuan untuk diri sendiri tanpa adanya gangguan dari orang lain. Apapun aktifitas para lajang, diharapkan dapat memenuhi kebutuhan hidup pribadi.Para lajang ini menganut paham kebebasan. Mereka tidak perlu merasa cemas atau takut terhadap tuntutan dari orang lain atau norma sosial masyarakat karena mereka tidak mengganggu orang lain.

\section{METODE PENELITIAN}

Jenis penelitian yang dilakukan penelitian kualitatif dengan pendekatan studi kasus yang bertujuan memahami gambaran yang lebih mendalam tentang wanita karier serta fenomena pilihan hidup tidak menikah di Kota Ende Kabupaten Ende. Fokus pada wanita karier yang tidak menikah.Informan ditentukan secara purposive sampling, teknik pengumpulan data yaitu observasi, wawancara dan dokumentasi, kemudian dianalisis 
melalui tahapan pengumpulan data (data collection), reduksi data (data reduction), penyajian data (display data), penarikan kesimpulan (conclusion) dan menggunakan teknik keabsahan melalui ketekunan pengamatan dan triangulasi data.

\section{PEMBAHASAN}

Berdasarkan hasil hasil penelitian dapat diketahui bahwa faktor-faktor penyebab informan memutuskan hidup melajang adalah:

1) Terlanjur memikirkan karier dan pekerjaannya. Dalam teori Feminisme, kaum wanita ingin memperjuangkan hak-haknya agar dapat setara dengan laki-laki, erat berkaitan dengan konflik kelas ras, khususnya konflik gender. Dalam teori sastra kontemporer, feminis merupakan gerakan wanita yang terjadi hampir di seluruh dunia. Gerakan ini dipicu oleh adanya kesadaran bahwa hak-hak kaum wanita sama dengan kaum lakilaki.Dalam bidang-bidang sosial, pekerjaan, pendidikan, dan lebih-lebih politik hakhak kaum ini memang lebih inferior ketimbang apa yang dapat dinikmati oleh lakilaki. Apalagi masyarakat tradisional yang berorientasi agraris cenderung menempatkan kaum laki-laki didepan, diluar rumah, dan kaum perempuan di rumah.Dengan adanya teori Feminis, bilangan wanita yang bekerja semakin meningkat. Wanita karier ini bekerja lebih dari memperoleh penghasilan, namun juga ingin berprestasi, bermakna bagi orang lain, mengaktualisasikan diri dan mengubah image yang selama ini menyatakan mereka tidak mempunyai kemampuan bekerja optimal. Hal ini semakin didukung dengan perkembangan zaman yang mengakibatkan semakin meningkatnya kesetaraan gender antara wanita dan laki-laki, sehingga memungkinkan para wanita karier ini cenderung dengan tegas memilih hidup melajang tanpa memperdulikan anggapan masyarakat karena bagi mereka perkawinan bukan merupakan suatu keharusan.Sama halnya yang terjadi di Kota Ende kabupaten Ende, dimana peneiti menemukan terdapat banyak wanita-wanita yang terjun dalam bidang pekerjaan. Mereka bekerja bukan sekedar mengaktualisasikan diri, melainkan ingin memperbaiki perekonomian keluarga. Dengan segala kesibukan dalam dunia pekerjaan, para wanita pekerja ini sampai-sampai mengenyampingkan urusan menikah atau berumah tangga. Seperti yang peneliti temukan di Kelurahan Mautapaga Kota Ende Kabupaten Ende, terdapat 3 orang wanita karier yang sampai saat ini hidup melajang dikarenakan lebih ingin memfokuskan diri dengan kariernya.

2) Adanya prioritas-prioritas kehidupan lainnya. Perkawinan bukan satu-satunya cara mendapat kebahagiaan. Apalagi saat ini perkawinan tidak selamanya bahagia, terlihat 
dengan semakin meningkatnya kekerasan dalam rumah tangga, poligami maupun perceraian. Informan merasa saat ini prioritas diarahkan sebagian untuk Tuhan dan sebagian untuk kebutuhan duniawi.

3) Ingin menjalani kehidupan pribadi secara bebas. Hal ini sejalan dengan Feminis liberal yaitu pandangan untuk menempatkan perempuan yang memiliki kebebasan secara penuh dan individual. Aliran ini menyatakan bahwa kebebasan dan kesamaan berakar pada rasionalitas dan pemisahan pada dunia privat dan public. Setiap manusia demikian menurut mereka punya kapasitas untuk berpikir dan bertindak secara rasional, begitu pula pada perempuan. Akar ketertindasan dan keterbelakangan pada perempuan ialah karena disebabkan oleh kesalahan perempuan itu sendiri. Perempuan harus mempersiapkan diri agar mereka bisa bersaing di dunia dalam rangka "persaingan bebas" dan punya kedudukan setara dengan laki-laki.Tokoh aliran ini adalah Naomi Woolf, sebagai "feminism kekuatan” yang merupakan solusi. Kini perempuan telah mempunyai kekuatan dari segi pendidikan dan pendapatan. Perempuan juga harus menuntut persamaan haknya serta saatnya kini perempuan bebas berkehendak tanpa bergantung pada laki-laki.Feminism liberal berusaha untuk menyadarkan wanita bahwa mereka adalah golongan tertindas. Pekerjaan yang dilakukan wanita di sektor domestic dikampanyekan sebagai hal yang tidak produktif dan menempatkan wanita pada posisi sub-ordinat. Budaya Amerika yang materialistis, mengukur segala sesuatu dari materi, dan individualis sangat mendukung feminisme. Wanita-wanita tergiring keluar rumah, berkarier dengan bebas dan tidak bergantung pada pria.

4) Perasaan dibutuhkan oleh keluarganya di rumah. Saat kecil orangtua yang selalu merawat kita. Inilah saatnya kita membalas jasa mereka. Informan pada kasus 3 sejak kecil hidup bersama kedua orangtuanya. Ia hanya memiliki satu orang saudara kandung, jadi kita sudah bisa mengira-ngira, kasih saying seperti apa yang sudah ia dapatkan dari ibu bapaknya. Saat ini ibu bapaknya sudah sangat lemah dan tidak mampu lagi melakukan banyak aktifitas. Walaupun ia memilik aktifitas yang cukup padat, namun perhatiannya pada keduanya tidak pernah ia tinggalkan. Ia merasa kasihan pada kedua orang tuanya, ketika ia harus menikah dan harus meninggalkan keduanya di rumah.

5) Ketakutan akan permasalahan dan konflik rumah tangga. Banyaknya kekerasan dalam rumah tangga dan berujung pada perceraian. Ia juga sering mendengar cerita dari rekan kerjanya yang sudah berkeluarga, ada yang pusingkan persoalan tidak 
sejalannya pemikiran dengan suami, ataupun bertambahnya kebutuhan perekonomian saat ini, kebutuhan sekolah anak yang semakin hari semakin tinggi, juga persoalan ketidak harmonisan dengan mertua. Hal inilah yang semakin menunjang pilihan hidup tidak menikah beliau.

Dengan kesibukannya dalam dunia pekerjaan, para wanita karier ini tetap menjaga silaturahmi yang baik dengan masyarakat sekitar.Mereka juga memiliki jiwa sosial yang tinggi dan memiliki hubungan yang baik dengan lingkungan sosialnya Seperti mengikuti pengajian majlis ta'lim (tidak teralalu rutin), menghadiri kegiatan-kegiatan sosial, ada juga yang sangat aktif dalam kegiatan-kegiatan kemasyarakatan seperti mengikuti kegiatan sosial di lingkup Gereja dan aktif memandu renungan dari bacaan kitab suci.

Masyarakat sekitar pun memiliki pandangan yang positif terhadap beberapa wanita karier yang memilih hidup melajang.Para wanita karier lajang ini tetap menjaga nama baik, serta menjunjung tinggi harkat dan martabat keluarga. Melihat lingkungan tempat tinggal yang masih begitu erat nilai-nilai kebudayaannya, mereka tidak berani melakukan hal-hal diluar batasan sehingga pilihan hidup melajang ini dianggap sebagai suatu pengorbanan positif yang mereka lakukan karena lebih ingin memfokuskan diri dalam berkarier.

\section{KESIMPULAN}

Berdasarkan hasil penelitian yang dilakukan terhadap wanita karier yang memilih tidak menikah di Kota Ende Kabupaten Ende, tentangfaktor-faktor yang melatar belakangi wanita karier memilih tidak menikah dan bagaimana interaksi wanita karier yang memilih tidak menikah dalam masyarakat dapat ditarik kesimpulan bahwa wanita karier yang memilih tidak menikah dilatar belakangi oleh bebrapa hal berikut: (1) Terlanjur memikirkan karier dan pekerjaannya. (2) Adanya prioritas-prioritas kehidupan lainnya. Informan merasa perkawinan bukan satu-satunya cara mendapat kebahagiaan (3) Ingin menjalani kehidupan pribadi secara bebas(4) Perasaan dibutuhkan oleh keluarganya di rumah. (5) Ketakutan akan permasalahan dan konflik rumah tangga.

Interaksi wanita karier yang memilih menikah terhadap masyarakat sekitar dengan mengikuti pengajian majlis ta'lim (tidak teralalu rutin) menghadiri kegiatankegiatan sosial, ada pula yang sangat aktif dalam kegiatan-kegiatan kemasyarakatan seperti mengikuti kegiatan sosial di lingkup Gereja dan aktif memandu renungan dari bacaan kitab suci. 
Volume III No. 1 Mei 2015

ISSN e-2477-0221 p-2339-2401

\section{DAFTAR PUSTAKA}

Anastasiaosa.blogspot.com. (2013). (online). (Wanita karier dan Feminisme.Diakses 28 Juni 2015).

Azmi, Rohali Yuli. (2013).. (Online). (Feminisme - Wikipedia bahasa Indonesia, ensiklopedia bebas, diakses 23 April 2015).

Caecilia.(2007). (Online) Faktor-Faktor Penyebab Wanita Karier Memilih Hidup Melajang. Skripsi Tidak diterbitkan. Semarang: Universitas Katolik Soegijapranata.

Dariyo, A. (2003).Psikologi Perkembangan Dewasa Muda. Jakarta: Grasindo.

Eriany, P. (1997). Menikah Atau Hidup Melajang Pilihan Wanita Masa Kini. Jurnal Pranata. Semarang: Soegijapratana Catolic University Press. Vol VII. No 3 (1-6).

Gibson., Ivanevich., Donnely. (1990). Organisasi. Jakarta: Erlangga.

Hurlock, E. B. (2004). Psikologi Perkembangan Suatu Pendekatan Sepanjang Rentang Kehidupan. Jakarta: Erlangga. (Edisi Kelima).

Hidayah, Rani dkk. (2013). Wanita Karier Masa Kini.(Online). (http ://dehazel. blogspot. com/2013/ 04/v- behavior urldefaul tvmlo. html, diakses 23 April 2015).

Jacobs, A. (2001) .A Feminist Writer and 'Spinster by Choice' Hammers Away at The Registry of Reason to Get Meriied. www.jsonline.com (23 April 2015)

Kutha Ratna. (2004). Teori, Metode, dan Teknik Penelitian sastra.Denpasar: Pustaka Pelajar (Online),www. Slideshare.net/syawiri/Makalah. Teori. Feminisme.(diakses 24 April 2015).

Kartini, P. (2005). Wanita Harus Mandiri. Dalam Wawasan. Surat Kabar Harian, 24 April 2005. Semarang.

Lumy, Benyamin. (2014). Efek Buruk Terlambat Menikah.(Online).(http://life.viva.co.id/news/read/546797-6-efek-buruk-terlambatmenikah/. diakses 23 April 2015).

Moleong, L. J. (2005). Metodologi Penelitian Kualitatif. Bandung: PT. Remaja Rosdakarya. (Edisi Revisi).

Moleong, L. J. (1990). . Metodologi Penelitian Kualitatif. Bandung: PT. Remaja Rosdakarya. (Edisi Kedua)

Ollenburger, J. C. \& Moore, H. A. (2002) .Sosiologi Wanita. Jakarta: PT. Rineka Cipta

Poerwandari, E. K. (1998). Pendekatan Kualitatif dalam Penelitian Psikologi. Jakarta: Lembaga Pengembangan Sarana Pengukuran dan Pendidikan Sosiologi.

Pusat Bahasa departemen Pendidikan Nasional, (2005).Kamus Besar Bahasa Indonesia, Jakarta: Balai Pustaka. 
Riyanto, J. (2005). Perempuan dan Tugas Karier. Dalam Suara Merdeka. Surat Kabar Harian, 12 Maret 2005. Semarang: PT. Suara Merdeka Press.

Suryabrata.(2011). Metodologi Penelitian. Jakarta: Rajawali Press.

Tim Penyusun FKIP Unismuh Makassar.(2012). Pedoman Penulisan Skripsi. Unismuh Makassar: Panrita Press. 